\title{
ADMINISTRATIVE RESPONSIBILITY IN THE CONSTRUCTION INDUSTRY
}

\section{Nenko S. S.}

\section{INTRODUCTION}

From an economic point of view, construction activity is a process of construction of buildings and structures, creating new enterprises, realize the expansion, reconstruction and technical re-equipment of existing enterprises and other objects the production sector and service sector, or in other words, it - economic activity, which includes forecasting, planning, design, construction of urban development, landscaping, expansion, technical reequipment of enterprises and provides the construction, reconstruction of residential, public and industrial buildings, structures and creates the basis for the development of all other spheres of the national economy.

\section{The concept and grounds of administrative responsibility in the construction industry}

The reform of the construction industry in the context of decentralization of the public administration system has influenced the gradual simplification of licensing and registration procedures, while expanding the powers of local governments and local Executive authorities in the field of architectural and construction control and increasing the responsibility of all participants in the construction process.

These changes are aimed at the proportionality of the application of the imperative and dispositive method in public relations in the construction industry. Due to this, considerable attention is paid to the formation of public-service relations in the industry under study, which are aimed at the interaction of the subjects of the construction process and inspection bodies. Public-service relations assume bilateral interaction of bodies of architectural and construction control and other subjects of construction process according to which one party has to provide the corresponding documents (the statement, the Declaration), and in the specified terms to make one of certain decisions, to provide permission, the certificate for construction or to refuse issue of allowing documentation.

With the help of public service relations, each of the parties is endowed, along with the rights, with certain obligations that are associated with the 
stages of construction. The most detailed can be their guide, guided by the stages of the construction process ${ }^{1}$ :

a) at the stage of preparatory works-in order to obtain the right to perform preparatory works, the customer submits a notification (Declaration) to the state architectural and construction control bodies, in turn the latter are obliged to enter it into the Unified register of documents, which gives the right to perform preparatory and construction works, and certifies the acceptance of completed construction projects into operation;

b) at the stage of construction works-the customer submits a notification (Declaration) or receives a permit, which is associated with the category of complexity of objects, in turn, the state architectural and construction control bodies are obliged to decide on the issuance or refusal to issue a permit for construction works and enter the data in the Unified register of documents, after which the customer can begin construction work;

c) at the stage of commissioning of completed construction projects, the customer submits a statement or receives a certificate about readiness of object for operation, which is associated with the complexity of objects; in turn, the authorities of the state architectural and construction supervision are required to make a decision about issuance or refusal to issue certificate for the construction work, and enter data in the Unified register of documents, then the customer may begin construction work.

This means that such relations are not built on a one-sided scheme of power-subordination, but on a two-way scheme of mutual right of claim belonging to both sides of legal relations ${ }^{2}$.

However, in case of violation or non-compliance with certain obligations by the subjects of the construction process at the appropriate stages, the inspection bodies have the right to apply appropriate administrative and coercive means of influence, among which the priority is given to administrative responsibility.

At present, the concept of administrative responsibility has a multi-vector orientation, connected, firstly, with the absence of its consolidation in the administrative-delict legislation; secondly, different approaches of scientists to its understanding and interpretation.

The concept of administrative responsibility is considered by scientists as one of the institutions of administrative law, as a form of ensuring one of the

\footnotetext{
${ }^{1}$ Isaenko D. Seven steps to decentralize the system of state Architectural control: teaching method. benefit. Kyiv: world Bank group 1818 N. Street N.W. Washington, D.C., 204ZZ, 2015. $64 \mathrm{p}$.

${ }^{2}$ Democratic foundations of public administration and administrative law: a monograph. / Y. Shemshuchenko, V. Averyanov, O. Andriyko, etc. Kyiv: Yurid. thought, 2010. 496 p.
} 
coercive measures, as a kind of legal responsibility, as an effective means of preventing offenses and ensuring law and order, as a certain state of public relations, which arises as a result of violation of legislation ${ }^{3}$. This list of starting categories, laid down in the interpretation of administrative responsibility, becomes the impetus for numerous discussions on this issue.

In turn, D. Lukyanets examines the Institute of administrative responsibility through administrative-tort relations, correlates the grounds of this type of legal responsibility with the elemental composition of legal relations. Detailing the specified conceptual approach, it identifies object of legal relations with object of an offense; their maintenance with the objective party of an administrative offense; the legal fact which underlies emergence of legal relations, with the subjective party of an offense. In the context of the above, he points to the ratio, but not the identification of relations administravtinogo offenses, administrative-tort relations and relations of administrative responsibility ${ }^{4}$.

Starting from the elemental structure of these legal relations, D. Lukyanets, defines the normative model of administrative responsibility, which consists of the General foundations and grounds for the emergence of administrative responsibility; the legal status of administrative jurisdiction and persons to whom penalties are applied; the procedural form of application and execution of penalties; principles and list of penalties.

In turn established categories operates T. Kolomoets, specifying administrative responsibility for the kind of legal liability, which is a specific form of negative response from the state represented by authorized bodies of the corresponding category of illegal actions (primarily of administrative offences), and the perpetrators of such crimes must answer before the authorized state body for its unlawful actions and to incur administrative penalties prescribed by the law and order ${ }^{5}$. This position of interpretation of administrative responsibility is laid down in the Academic course on administrative law (edited by V. Averyanov) ${ }^{6}$.

Along with this, Y. Bityak, V. Garashchuk and V. Bogutsky define administrative responsibility as a form of ensuring one of the coercive measures associated with the imposition on the offender of mandatory rules

\footnotetext{
${ }^{3}$ Course of administrative law of Ukraine: studies. / V. Kolpakov, O. Kuzmenko, I. Pastukh et al. Kyiv: Yurinkom inter, 2012. 808 p.

${ }^{4}$ Lukyanets D. Development of the Institute of administrative responsibility: conceptual foundations and problems of its implementation: dis. ... the doctor said. Sciences: 12.00.07. Kiev, 2007. 435 p.

${ }^{5}$ Kolomoets T. Administrative law of Ukraine. Academic course: studies. Kyiv: Yurinkom Inter, 2011. 576 .

${ }^{6}$ Bostan L. M. History of state and law of foreign countries: studies. Handbook / L. Bostan, S. Bostan. Kyiv: center of educational literature, 2004. 672 p.
} 
in force in the state administration, administrative penalties, entailing for these person's burdensome consequences of a material or moral nature ${ }^{7}$.

The starting point for imposing administrative penalties is violations of the normative rules in the public administration, which thus provides for the prosecution of officials of public authorities in most cases.

With regard to this, S. Petkov notes that in modern conditions of the state, the subject of management is responsible for all adverse consequences caused by illegal or inept use of power. In this regard, the institution of administrative responsibility should be directed to the definition and ordering of administrative offenses, the subject of which a priori can only be an official of public authorities. Thus, speaking about administrative responsibility, it should be noted that it is the responsibility of officials of public authorities.

Developing this position, some scientists note that the subject of responsibility for such offenses is an ordinary citizen. Regarding this, there are numerous discussions, which are reflected in the proposals for the construction of an updated code on administrative responsibility, the subject of administrative offenses in accordance with which officials of public authorities should become.

Summarizing the above, we note that administrative responsibility is a purely legal phenomenon, generated by the legal regulation of the relevant relations. And as a legal phenomenon, administrative responsibility in the construction industry is characterized by two groups of signs. The first group is the signs inherent in the whole of administrative responsibility. The second group-features that distinguish administrative responsibility in the construction industry from administrative responsibility in other spheres of public life ${ }^{8}$.

In the science of administrative law formed several views on administrative responsibility in the construction industry. Let us draw attention to the fact that representatives of the science of administrative law, considering administrative responsibility in the construction industry, reveal only the General features of administrative responsibility. This approach has its negative consequences, because the specificity and features of administrative responsibility in the construction industry are lost. And as a consequence of this one-sided understanding of administrative responsibility in the field of construction, problems may arise in the practical implementation of administrative-tort norms.

\footnotetext{
${ }^{7}$ Administrative law: studies. / Y. Bytyak, V. Garashchuk, V. Bogutskaya, etc. Kharkiv: Pravo, 2010. 624 p.

${ }^{8}$ About attraction to administrative responsibility for violation of the town-planning legislation. Comparative-analytical law. 2013. No. 4/1. P. 241-243.
} 
At the same time, representatives of the science of construction law, considering administrative responsibility, focus mainly on the specific features of this responsibility in the construction industry, ignoring the General properties of administrative responsibility.

Such an approach can lead to the fact that the legislator will not take into account in his law-making activities the General trends in the development of the institution of administrative responsibility, and only try to settle relations in the construction industry, which is in a state of constant reform. It is like trying to examine the whole by its individual manifestations, but without forming a clear idea of the whole as such. However, it is necessary to find out what makes it possible to create a holistic view of administrative responsibility ${ }^{9}$ in the construction industry.

That is why, characterizing administrative responsibility in the construction industry, it is necessary to take into account the theoretical developments of legal science in General and the norms of administrative law and legislation on construction activities.

Administrative offenses in the studied industry are characterized by common features inherent in any administrative offenses. However, a number of scientists highlight the features inherent in administrative responsibility in construction activities, which they include:

(a) the specific scope of administrative responsibility - construction activities;

(b) the subjects of administrative responsibility are individuals, officials and legal entities;

(c) application of penalties only of property character ${ }^{10}$.

A significant difference that allows you to select them in an independent group, from the point of view of life. M. Semenko, is the object of encroachment, that is, public relations existing in the field of construction, and its normal uninterrupted work ${ }^{11}$.

In the theory of administrative law as the object of an administrative offense is determined by what encroaches administrative offense, namely the range of protected by administrative legislation of public relations ${ }^{12}$.

${ }^{9}$ Lukyanets D. Administrative-tort relations in Ukraine: theory and practice of legal regulation: monograph. Sumy: VTD "University book", 2006. 367 p.

${ }^{10}$ Tropina G. Legal nature of administrative responsibility in the field of construction. European perspective. 2013. No. 9. Pp. 79-86.

${ }^{11}$ Semenko B. administrative responsibility for offenses in the field of construction: dis. Cand. J. Sciences: spec. 12.00.07 "Administrative law and process; financial law; information law". Zaporozhye, 2011. 193 p.

${ }^{12}$ Mikolenko A. Administrative process and administrative responsibility in Ukraine: studies. Benefit. Kharkiv: Odyssey, 2006. 352 p. 
Analyzing the specified provision, it is necessary to stop in more detail on the analysis of the types of objects of administrative offenses defined in the theory of administrative law in the investigated direction: General, generic and direct.

The General object covers a circle of the public relations defined in tasks of the Code of Ukraine about administrative offenses (Art. 1) and defined within concept of an administrative offense (Art. 9.) ${ }^{13}$. From a doctrinal point of view, it includes all public relations (administrative, labor, financial, etc.) protected by administrative law ${ }^{14}$. In this regard, a very erroneous point of view is to reduce it only to public relations of a managerial nature. Interpreting this as a circle of protected public relations in the construction industry, I. Mironets to public relations, forming a common object, refers only to the sphere of state management of construction activities, which is regulated by regulations ${ }^{15}$. However, we must not forget that administrative offenses actually encroach on other social relations (regulated, for example, by the norms of constitutional, financial, labor law), which are also protected by administrative and legal means ${ }^{16}$. In this regard, a common object in the studied direction is the range of public relations in the construction industry, which are protected by administrative and legal norms.

The generic object is a group of homogeneous public relations aimed at the realization of the rights and freedoms of citizens, ensuring the established order of management, formation and development of a fullfledged human environment, through the sustainable development of human settlements, landscaping, nature protection and cultural heritage, the use of natural resources, coordination of state, public and private interests. In some scientific works, the definition of generic object in the studied direction is carried out within the framework of public relations in the field of capital construction $^{17}$, is limited to the administrative offenses specified in Chapter 8 "Administrative offenses in the industry, construction and in the field of use of fuel and energy resources". The opposite view supported by a

${ }^{13}$ Code of Ukraine on administrative offences. Information of the Supreme Soviet of the USSR. 1984. Annex to No. 51. P. 1122 (with the following modifications and additions).

${ }_{14}$ Administrative law of Ukraine. Academic course: studies.: in 2 t. / per zag. ed. Averyanova. Kiev: The Faculty Of Law. thought, 2004. Vol. Common part. 584 p.

${ }^{15}$ Mironets I. Administrative and legal regulation of construction activity in Ukraine: dis. ... the candidate is legal. Sciences : 12.00.07. Kiev, 2012. 235 p.

${ }^{16}$ Kostrubitska A. There is Administrative responsibility for law-violations in the fuel and energy complex of Ukraine: dis. ... the candidate is legal. Sciences: 12.00.07. Kiev, 2009. 222 p.

${ }_{17}$ Kropacheva A. Administrative responsibility for violations in the field of capital construction: abstract. dis. on competition of a scientific degree - nie Kazan. the degree candidate. Yuri. Sciences: spec. 12.00.14 "Administrative law; administrative process". Moscow, 2013.20 p. 
large number of scientists, focusing on the branching of administrative violations in the construction industry within at least five chapters of the Cao, which indicates the inter-industry focus in legal relations ${ }^{18}$.

Defining the direct object, it is necessary to emphasize its individuality for each administrative offense in the construction industry, as an examplethis is public relations in the field of land use of road transport, subsoil protection, use of land of the state forest Fund, the sphere of management of the construction industry. At the same time, this is the established procedure for conducting a comprehensive examination of project documentation for construction, obtaining permits, investment activities in construction and the like. The scope of the direct object is clearly defined circle protected by the administrative norm of public relations, which are harmed by a specific offense related to the implementation of construction activities.

Thus, it should be noted that construction activity is associated with a set of labor, land, financial, civil, economic relations, for example, the allocation of land for construction; regulation of financial mechanisms for investment in housing construction. In this regard, it should be noted that the composition of administrative offenses in the construction industry on the object of illegal encroachment can be systematized into two groups: group 1-public relations, regulated directly by the construction legislation; Group 2-social relations regulated by other branches and institutions of law, but they arise in connection with the implementation of construction ${ }^{19}$.

Considering the external signs and circumstances that form an administrative offense, we focus on the analysis of the objective side of the element component, which includes acts (action or inaction), the harmful consequences of the offense, the causal consequences between them.

The analysis of the objective side of administrative offenses in the construction industry gives grounds to group them into the following groups: violation of mandatory requirements of state standards, specifications, building codes and rules (construction legislation) at all stages of the construction process; violation of sanitary-epidemiological, environmental, fire-prevention norms and rules of improvement during construction; unauthorized construction; - violation of the procedure for; violations related to the order of implementation of copyright and technical supervision; violations related to failure to comply with the legal requirements of officials; other violations related to the construction process.

18 Nizankowska N. Administrative liability for offenses in the sphere of housing construction : abstract. dis. on the receipt Kazan. the degree candidate. Yuri. Sciences: spec. 12.00.14 "Administrative law; administrative process". Khabarovsk, 2011. $20 \mathrm{sec}$.

19 Parmenov S. Administrative responsibility in the construction industry. Republican construction newspaper. 2012. No. 39 (492). 
Considering the specified acts which in total form the objective party of administrative offenses in construction branch, once again it is necessary to focus attention on the interpectoral direction of the corresponding branch. Separate from the specified illegal acts form structures of transport, housing, land and offenses in the sphere of nature management, for example violation of the approved town-planning documentation at allotment of lands and the illegal actions of the officials and legal entities which have entailed unauthorized occupation of lands (Art. 211 of the Land code of Ukraine) ${ }^{20}$. All this in a complex indicates the need to allocate a separate block of misconduct in the construction industry.

Subjects of administrative responsibility in the construction industry can be both individuals and legal entities. Depending on the stage of the construction process, during the implementation of which an administrative offense is committed, there are such subject composition ${ }^{21}$ : at the design stage - design organizations, chief architect of the project, chief engineer of the project, expert organizations, officials of expert organizations, organizations providing technical conditions; at the stage of implementation of preparatory works - the customer, officials of the customer, contractor, officers, contractors, officials exercising technical supervision, the officials carrying out supervision; at the stage of construction work - the customer, officials of the customer, contractor, officers, contractors, officials exercising technical supervision, the officials exercising supervision; at the stage of production and manufacture of building materials, products, structures - legal entities and individuals-entrepreneurs, individuals and officials; at the stage of operation of completed construction facilities-legal entities and individuals-entrepreneurs, individuals and officials.

At the same time, analyzing the subject structure of administrative offenses in the construction industry, they can be classified depending on the direction of personal activity in the construction industry. Such subjects include: subjects of urban development, engaged in the design of objects, the examination of construction projects; subjects of urban development, which are customers of the construction of objects (in the case of urban development activities), or performing the functions of the customer and the contractor at the same time; subjects of urban development, performing construction work; the subjects of urban development, which carry out economic activity, connected with creation of architectural objects is subject

\footnotetext{
${ }^{20}$ Korneev Y. Land law: studies. benefit. 2nd view. processing. Kyiv: center of educational literature, 2011. $248 \mathrm{p}$.

${ }^{21}$ Isaenko D. Seven steps to decentralize the system of state Architectural control: teaching method. benefit. Kyiv: world Bank group 1818 N. Street, N.W. Washington, D. C., 204ZZ, 2015. 64 p.
} 
to licensing, or entrust the execution of certain types of works the responsible executors which under law must have the qualification certificate; the subjects of urban development that produce building materials, products and structures; subjects of urban development, attracted by the Central body of Executive power that implements the state policy on state architectural-building control, to audit; the enterprises providing technical conditions on engineering support of object of construction, etc.

Given the reconstruction of administrative-tort legislation in the studied direction is offered within the separate chapters of the administrative code "Administrative offences in construction industry" include: compositions of administrative offenses relating to violations in the sphere of protection of natural resources during construction; the compositions of administrative offenses relating to violations of fire, sanitary-epidemiological, environmental supervision at construction sites and adjacent to a building site; warehouses of administrative offenses concerning improvement of settlements (violation of arrangement of the adjacent territory to the construction object, damage to the adjacent transport infrastructure by construction works, etc.); warehouses of administrative offenses concerning violations on creation of engineering and transport infrastructure within the construction object; the compositions of administrative offenses relating to housing rights and freedoms of citizens (alteration and reconstruction of buildings, damage to premises); the compositions of administrative offenses relating to violations in the creation of unhindered living environment for persons with disabilities and other disabled groups; the compositions of administrative offences related to the exercise of architectural control, technical supervision and other regulatory powers of public authorities related to the construction; the compositions of administrative offences of non-compliance with energy efficiency and energy conservation construction projects; the components of administrative offences related to the financing of construction; the components of administrative offences, related with connecting to infrastructure construction projects; the components of administrative offences related to publicize activities and providing administrative services in the construction industry.

An integrated approach in building this Chapter aims to systematize the scattered under the construction law and the administrative code of administrative offenses related to construction.

\section{Administrative liability procedures in the construction industry}

Gradual steps towards reforming relations in the construction industry were the impetus for the transfer of construction control and supervision from the national level to the local. This restructuring of the system of state 
supervision over decision - making in the field of urban planning and proper state architectural and construction control requires the introduction of effective and transparent administrative and jurisdictional procedures in the construction industry. The substantive basis of administrative and jurisdictional procedures are administrative liability procedures in the construction industry, aimed at the consideration of cases of administrative offenses.

The definition of the essence and content of administrative and jurisdictional procedures in the construction industry should be investigated through the formation of scientific views on the identification of the concepts of "process", "production" and «procedure". The reason for the detailed analysis of General theoretical concepts of the administrative process is the study of the most established doctrine of administrative law approaches to the essence and content of the categories "administrative process", "administrative proceedings", "administrative procedure" 22.

Stages of implementation of the procedure for consideration of cases of administrative offenses: initiation of a case of an offense in the construction industry; consideration of a case of an offense in the construction industry; appeal against the decision to impose a fine and the decision to close the case; execution of the decision.

And the stage is the initiation of a case of an offense in the construction industry. In this stage it is possible to allocate the following procedural stage: a) preliminary administrative investigation during which carrying out there is an identification and suppression of an offense, fixing of traces on a scene, interrogation of eyewitnesses; b) investigations: drawing up the Protocol, selection of explanations, withdrawal of things and documents (collection of proofs), fixing of results of investigation in procedural documents; c) transfer of business on jurisdiction for consideration.

Stage II-consideration of the case of an offense in the construction industry. At this stage is preparing the case for review, during which an official body of the state architectural and construction control: studying the case materials and determines the competence of the case; ascertain the correctness of the Protocol; organizes the notification to the subject of urban development, who shall be held liable and other persons participating in the proceedings, the time and place of the hearing; met with proof, carries out the reclamation of necessary additional materials; finds out, whether petitions (in the presence) of the subject of town-planning brought to

${ }^{22}$ Semenko B. administrative responsibility for offenses in the field of construction: dis. Cand. J. Sciences: spec. 12.00.07 "Administrative law and process; financial law; information law". Zaporozhye, 2011. 193 p. 
responsibility, or other persons participating in business are subject to satisfaction.

Stage III-appeal against the decision to impose a fine and the decision to close the case. An important guarantee of the legality and validity of the application of administrative penalties is the presence of the stage of revision of resolutions. This stage has a special place in the structure of proceedings in cases of administrative misconduct. Under review understand consideration of cases by bodies entrusted with the control over the legality of decisions on cases of administrative offenses or re-examination of cases by bodies that have made a decision ${ }^{23}$.

Stage IV - implementation of the resolution. The final stage of proceedings in cases of administrative misconduct in the construction industry is the execution of decisions on the imposition of administrative penalties.

\section{Penalties in the construction industry}

In Ukraine there is a need for purposeful activities of the state towards the development of those industries that can provide multiplicative effect in adjacent areas and, as a consequence, the economic growth of the country. One such industry is construction.

Construction is the material basis for improving the level and quality of life of the population, which is proclaimed in Ukraine the goal of long-term socio-economic policy of the state. The current situation allows us to state the insufficient efficiency of regulation of market relations in the construction sector. This requires additional studies of current trends in the development of construction in order to improve the forms, methods and tools of state influence on the transformation and market processes in the construction industry in the direction of compliance with the requirements established by legislation, building codes, state standards and rules.

Administrative responsibility in the construction industry is one of the important tools to ensure compliance with the above requirements, enshrined in state standards, building codes and regulations. This type of administrative responsibility is implemented by imposing administrative penalties on the guilty subjects of the construction process.

Administrative penalties are punitive, "punitive" sanctions, which usually consist in deprivation or restriction of certain rights, benefits, education of a person in the spirit of compliance with the laws of Ukraine,

\footnotetext{
${ }^{23}$ Stukalenko O. Administrative responsibility for violation of norms of the land legislation (material and procedural aspect): dis. ... candidate of Jurid. Sciences: 12.00.07. Odessa, 2008. $181 \mathrm{c}$.
} 
respect for the rules of the hostel, as well as prevention of committing new offenses both by the offender and by other person ${ }^{24}$. Thus the purpose of administrative penalty fixed by art. 23 .

The Code of Ukraine on administrative offences does not define the concept of "administrative restraint", stopping only at its purpose and types. Therefore, within the scientific literature there are different approaches to the interpretation of this concept. One group of scientists defines administrative sanctions because of the analysis of adverse legal consequences for the damage caused to administrative offenses (V. Averyanov, S. Pektvov) ${ }^{25}$. Another group investigates them through the material manifestation of administrative responsibility (O. Andriyko, D. Lukyanets, S. Stetsenko) ${ }^{26}$. In another aspect, administrative sanctions are investigated because of the component of administrative coercion (A. Komzyuk, T. Kolomoets, D. Priymachenko ${ }^{27}$. Along with this N. Khoroshchak summarizes the above approaches to the concept of administrative penalties in institutional, regulatory and legal aspects ${ }^{28}$.

The indicated approaches of scientists are actually reduced to a synonymous interpretation of the concept of administrative penalties from the position of the component of the legal norm, administrative responsibility, state coercion.

Within the framework of article 24 of the administrative Code, a certain system of administrative penalties: warning, fine, penalty points, compensated seizure of the object, confiscation, deprivation of a special right, community service, correctional labor, administrative arrest, arrest with detention in the guardhouse. This system of administrative penalties includes different in nature and legal consequences of sanctions, which allows to take into account when imposing penalties as features of the committed administrative offense and features of the offense ${ }^{29}$.

${ }^{24}$ The code of Ukraine on administrative offences: scientific and practical commentary / G. Kalyuzhny, A. Komzyuk, A. Pogrebnoy et al. 2nd ed. Kyiv: all-Ukrainian Association of publishers "Legal unity", 2008. 655 p.

${ }^{25}$ Administrative law of Ukraine. Academic course: studies.: in 2 t. / per zag. ed. Averyanova. Kiev: The Faculty Of Law. thought, 2004. Vol. Common part. 584 p.

${ }^{26}$ About attraction to administrative responsibility for violation of the town-planning legislation. Comparative-analytical law. 2013. No. 4/1. Pp. 241-243.

${ }^{27}$ Administrative responsibility in Ukraine: studies. allowance / per zag. ed. The 2nd kind., exp. Kharkov, 2001. 112 p.

${ }^{28}$ Harosak N. Administrative penalty according to the legislation of Ukraine: monograph. Kyiv: Institute of state and law. V. Koretsky NAS of Ukraine, 2004. 172 p.

${ }^{29}$ The code of Ukraine on administrative offences: scientific and practical commentary / G. Kalyuzhny, A. Komzyuk, A. Pogrebnoy et al. 2nd ed. Kyiv: all-Ukrainian Association of publishers "Legal unity", 2008. 655 p. 
Some of the above administrative penalties are imposed for violations in the construction industry.

Among the penalties provided by the current legislation for offenses in this area, fines occupy a prominent place and are the most common type of penalties. So, about administrative responsibility in construction, as M. Mironets notes, it is possible to speak mainly as about a penalty ${ }^{30}$.

In the framework of legislation and scientific literature provides a comprehensive interpretation of the concept of a penalty. Thus, in part 1 of article 230 of the Economic code of Ukraine penalties are defined as economic sanctions in the form of a sum of money (penalty, fine, penalty), which the participant of economic relations is obliged to pay in case of violation of the rules of economic activity, failure or improper performance of economic obligations ${ }^{31}$. Within the framework of this codified act, various types of implementation of economic sanctions in the form of penalties, fines, penalties are defined.

Thus, within the framework of the legislation, penalties are implemented in the form of a fine, penalty, penalty. The form of implementation of the penalty depends on the industry in which it is implemented. Taking this into account, the scientific literature distinguishes economic, financial and administrative sanctions, thus highlighting a certain kind of economic penalty, financial penalty, administrative penalty and civil penalty liability.

Taking into account the above, penalties are the implementation of the component of the legal norm, material and monetary sense, which is applied for violation of construction norms, rules and standards at all stages of construction activities to the subjects of the construction process, individuals, individual entrepreneurs, officials, legal entities.

The penalty is punitive in nature, not restorative. Committing an administrative offense in the construction industry, the subject pays a certain amount of money within the framework of the legislation, which is calculated in a clearly defined number of non-taxable minimum incomes of citizens, minimum wages and the like.

With the help individualization responsibility necessarily require installations such facts ${ }^{32}$ :

- the nature of the offense in the construction industry;

${ }^{30}$ Mironets N. Penalty liability for administrative offenses in construction activities. Lawyer. 2010. No. 6 (117). P. 34-38.

${ }^{31}$ Economic code of Ukraine of 16 January 2003 No. 436-IV. Sheets Of The Verkhovna Rada Of Ukraine. 2003. № 18, № 19-20, № 21-22. P. 144.

32 The code of Ukraine on administrative offences: scientific and practical commentary / G. Kalyuzhny, A. Komzyuk, A. Pogrebnoy et al. 2nd ed. Kyiv: all-Ukrainian Association of publishers "Legal unity", 2008. 655 p. 
- the person of the offender (natural person, natural personentrepreneur, official, legal entity);

- the extent of her guilt;

- property status (specialized participant in the construction process or an individual);

- circumstances mitigating or aggravating punishment.

Along with this, responsibility for some violations is differentiated depending on the complexity category of the construction object - the more complex the object, the higher the penalty. This approach can generally be considered justified within the framework of domestic legislation. But the question arises, how will the size of the fine be determined if the complexity category of the object in respect of which the violation took place is not defined ${ }^{33}$.

Analysis of penalties in the construction industry indicates significant shortcomings associated with: violation of the procedure for imposing fines; determination of their size; non-compliance in most cases, the purpose rules for imposing penalties for administrative offenses in the construction industry, which, in turn, violates the principles on which administrative responsibility is based (the principle of legality, the principle of individualization of responsibility).

Everything specified in the complex indicates the need to improve the procedure for imposing and determining the size of penalties. Thus, it is necessary:

1) to improve the procedure for imposing on the subject of urban development two or more fines for each committed administrative offense in the construction industry. Analysis of judicial practice in this regard indicates the need to coordinate the procedure for the simultaneous accrual of penalties for each offense committed in the construction industry. At the same time, the absence of a unified system in determining the composition of administrative offenses in the study area leads to the simultaneous drafting of the Protocol on administrative offense and the Protocol on offense in the field of urban development for similar offenses. The question on the simultaneous involvement of urban planning, primarily individuals for the same offense separately defined under the administrative code and the Law of Ukraine "On liability for violations in the field of urban development." This direction requires improvement in terms of systematization of offenses in the construction industry within the Construction code;

${ }^{33}$ Igonin V. Some novelties of the new law on liability for violations in the field of urban development. Legal newspaper. No. 7. 
2) agree on the amount of penalties defined in the administrative code and construction legislation. To this end, it is proposed within the framework of the Chapter of the Construction code to determine the list of offenses in the construction industry, detailing the subject of the offense (citizens, officials, individuals, entrepreneurs, legal entities). Taking into account the legal status of the above-mentioned subjects of the construction process, observing the implementation of the principles of administrative responsibility (legality, individualization), it is necessary to clearly delineate the boundaries of penalties for each offense, taking into account the subject of the construction process, which is brought to justice;

3 ) in order to harmonize the use of construction terminology within the disposition of articles, it is necessary to define it in detail in the conceptual apparatus of the code, which will avoid unnecessary confusion during its enforcement in the activities of jurisdictional bodies. This inconsistency significantly affects the detail within the Protocol on administrative offense, the legal norm that is violated, and also creates unnecessary confusion during the simultaneous Commission of two or more offenses by the subject of urban development. Along with this, it is necessary to coordinate the use of separately defined concepts "administrative offense in the construction industry" and "offenses in the field of urban development" within the framework of administrative and tort legislation, when committing which procedural documents are different in content. For the purpose of settlement of the specified question within the basic provisions of the Building code of Ukraine it is necessary to define the basic terms which are applied in dispositions of articles of administrative Code and the Law of Ukraine "about responsibility of subjects of town-planning". To harmonize the terminology used in the administrative-tort legislation, it is necessary to define the following concepts: administrative offense in the construction industry; state standards in the construction industry; building regulations; building rules and the like.

\section{CONCLUSIONS}

The study of administrative responsibility in the construction industry allows us to draw conclusions:

1. The analysis of the concept of administrative responsibility is carried out taking into account the existing scientific views on its content as one of the institutions of administrative law, as a component of administrative coercion as a type of legal responsibility, as a means of preventing offenses. Guided by established scientific views on the essence and origin of the specified legal category, we believe it is necessary to define the concept of 
administrative responsibility in the construction industry - as institute administrative responsibility, which is based on ALCO and building legislation, is implemented for the Commission by the subjects of construction process of administrative misconduct in the construction industry for which the competent public authorities in procedural order impose administrative penalty.

2. The grounds of administrative responsibility in the construction industry are considered: a) normative (legal); b) actual; c) procedural.

3. Factual basis. It is based on the concepts and elemental structure of the administrative offense in the construction industry (object, objective side, subject, subjective side).

4. The introduction of a number of socio-economic and legal reforms aimed at using the latest technologies in construction, increasing the level of optimization of the use of energy and natural resources, creating an unhindered living environment for people with limited mobility, comprehensive compliance with sanitary-epidemiological, fire-prevention norms and rules of improvement during construction, affects the emergence of new types of administrative offenses in the construction industry, for which it is necessary to establish responsibility. At the same time, the adaptation of the legislation of Ukraine to the legislation of the leading countries of the world requires appropriate steps to reform the administrative-tort legislation with the allocation of administrative offenses in the construction industry and bringing the construction legislation to a single system.

5. Within the framework of jurisdictional proceedings, a certain set of procedurally formed actions, administrative procedures aimed at the consideration of cases of administrative offenses is implemented.

The procedure of administrative responsibility in the construction industry should be defined as a set of clearly formed and consistent actions (stages), United by a common goal, during which the legal protection of the violated or disputed right is carried out, a legally authoritative decision is made, sanctions are applied, the violated right is restored in the process of considering an administrative case in the construction industry.

6. Describes the stages of implementation of the procedure of consideration of cases on administrative offences, which should include: the initiation of misdemeanor proceedings in the construction industry; the proceedings on offense in the construction industry; the appeal of the decision to impose a fine and orders to close the case; the execution of the decision. 


\section{SUMMARY}

The article is devoted to the study of modern views on administrative and legal support of the construction industry in the context of adaptation of the legal system in accordance with the "acquis communautaire". The problems of formation, formation and further development of the construction industry are investigated, trends and directions of improvement of administrative and legal support of construction activities are determined taking into account international standards.

The article focuses on the need to update the substantive provisions of the administrative and legal support of the construction industry by means of theoretical principles, elements of its mechanism, the system of subjects of construction activity, coordination of the provisions of administrative and tort legislation, as well as priority areas of harmonization of the current legislation with international provisions. The priority steps to improve the administrative and legal support of the construction industry in Ukraine are considered. Provides suggestions for improvement of the current legislation, in particular defined a comprehensive approach to the construction Chapter of the administrative code, as well as justifies the project structure and disclosed the main content of the Construction code, the scope of which covers the legal foundations of urban planning, construction engineering and other facilities in Ukraine.

\section{REFERENCES}

1. Administrative responsibility in Ukraine: studies. allowance / per zag. ed. The 2nd kind., exp. Kharkov, 2001. 112 p.

2. Administrative law: studies. / Y. Bytyak, V. Garashchuk, V. Bogutskaya, etc. Kharkiv: Pravo, 2010. 624 p.

3. Administrative law of Ukraine. Academic course: studies.: in 2 t. / per zag. ed. Averyanova. Kiev: The Faculty Of Law. thought, 2004. Vol. Common part. 584 p.

4. Bostan L. M. History of state and law of foreign countries: studies. Handbook / L. Bostan, S. Bostan. Kyiv: center of educational literature, 2004. $672 \mathrm{p}$.

5. Gnatyuk S. Stages of proceedings in cases of administrative offenses: dis. ... the candidate is legal. Sciences: 12.00.07 / Gnatyuk Stepan Sergeevich. New York, 2010. 228 p.

6. Economic code of Ukraine of 16 January 2003 No. 436-IV. Sheets of the verkhovna rada of Ukraine. 2003. № 18, № 19-20, № 21-22. Pp. 144.

7. Democratic foundations of public administration and administrative law: a monograph. / Y. Shemshuchenko, V. Averyanov, O. Andriyko, etc. Kyiv: Yurid. thought, 2010. 496 p. 
8. Igonin V. Some novelties of the new law on liability for violations in the field of urban development. Legal newspaper. No. 7.

9. Isaenko D. Seven steps to decentralize the system of state Architectural control: teaching method. benefit. Kyiv: world Bank group 1818 N. Street N.W. Washington, D.C., 204ZZ, 2015. 64 p.

10. Code of Ukraine on administrative offences. Information of the Supreme Soviet of the USSR. 1984. Annex to No. 51. Pp. 1122 (with the following modifications and additions).

11. The code of Ukraine on administrative offences: scientific and practical commentary / G. Kalyuzhny, A. Komzyuk, A. Pogrebnoy et al. $2^{\text {nd }}$ ed. Kyiv: all-Ukrainian Association of publishers "Legal unity", 2008. $655 \mathrm{p}$.

12. Kolomoets T. Administrative law of Ukraine. Academic course: studies. Kyiv: Yurinkom Inter, 2011. 576 p.

13. Korneev Y. Land law: studies. benefit. -2 nd view. processing. Kyiv: center of educational literature, 2011. $248 \mathrm{p}$.

14. Kostrubitska A. There is Administrative responsibility for lawviolations in the fuel and energy complex of Ukraine: dis. ... the candidate is legal. Sciences: 12.00.07. Kiev, 2009. 222 p.

15. Kropacheva A. Administrative responsibility for violations in the field of capital construction: abstract. dis. on competition of a scientific degree - nie Kazan. the degree candidate. Yuri. Sciences: spec. 12.00.14 "Administrative law; administrative process". Moscow, $2013.20 \mathrm{p}$.

16. Course of administrative law of Ukraine: studies. / V. Kolpakov, O. Kuzmenko, I. Pastukh et al. Kyiv: Yurinkom inter, 2012. 808 p.

17. Lukyanets D. Administrative-tort relations in Ukraine: theory and practice of legal regulation: monograph. Sumy: VTD "University book", 2006. $367 \mathrm{p}$.

18. Lukyanets D. Development of the Institute of administrative responsibility: conceptual foundations and problems of its implementation: dis. ... the doctor said. Sciences: 12.00.07. Kiev, 2007. 435 p.

19. Mikolenko A. Administrative process and administrative responsibility in Ukraine: studies. Benefit. Kharkiv: Odyssey, 2006. 352 p.

20. Mironets I. Administrative and legal regulation of construction activity in Ukraine: dis. ... the candidate is legal. Sciences : 12.00.07. Kiev, 2012. $235 \mathrm{p}$.

21. Mironets N. Penalty liability for administrative offenses in construction activities. Lawyer. 2010. No. 6 (117). P. 34-38.

22. Nizankowska N. Administrative liability for offenses in the sphere of housing construction : abstract. dis. on the receipt Kazan. the degree 
candidate. Yuri. Sciences: spec. 12.00.14 "Administrative law; administrative process". Khabarovsk, 2011. $20 \mathrm{sec}$.

23. Parmenov S. Administrative responsibility in the construction industry. Republican construction newspaper. 2012. No. 39 (492).

24. Semenko B. administrative responsibility for offenses in the field of construction: dis. Cand. J. Sciences: spec. 12.00.07 "Administrative law and process; financial law; information law". Zaporozhye, 2011. $193 \mathrm{p}$.

25. Stukalenko O. Administrative responsibility for violation of norms of the land legislation (material and procedural aspect): dis. ... candidate of Jurid. Sciences: 12.00.07. Odessa, 2008. 181 p.

26. Tropina G. Legal nature of administrative responsibility in the field of construction. European perspective. 2013. No. 9. P. 79-86.

27. Harosak N. Administrative penalty according to the legislation of Ukraine: monograph. Kyiv: Institute of state and law. V. Koretsky NAS of Ukraine, 2004. 172 p.

28. About attraction to administrative responsibility for violation of the town-planning legislation. Comparative-analytical law. 2013. No. 4/1. P. 241-243.

29. Legal responsibility: problems of definition and dismissal.; TNA. ed. Donetsk: PE "VD "Kalmius", 2013. 424 p.

Information about the author: Nenko S. S.,

Candidate of Law, Associate Professor, Professor at the Department of Administrative,

Criminal Law and Procedure, International University of Business and Law 37-A, 49 HGD str., Kherson, 73040, Ukraine 